\title{
In memoriam of Raymond Pahl Whose modern megalopolises?
}

\author{
Oleg N. Yanitsky \\ Doctor of Philosophy \\ Professor, Chief researcher \\ Institute of sociology Russian academy of sciences \\ Moscow, Russian Federation.
}

\begin{abstract}
The 'whose city?' question is acute today. The article is a brief inquiry in the meaning of this question posed by the UK sociologist R. Pahl in the early 1970s and to point out the changes in urban studies during the last decade. His appeal for a cumulative, systematic approach as well as for resistance against futuristically-oriented market research and a dictate of the developers are still valid. A growing social inequality issue is today as important as half-a-century ago. Describing the ontological premises of the concept of modern megalopolises, the following structures and processes should be taken into account: modern megalopolises are the sociobiotechnical systems (the SBT-systems) dependent on the global SBT-system which in turn tightly integrated by the information-communication technologies (IC-technologies); all kinds of them are interconnected by socio-ecological metabolic processes; modern megacities are involved into global geopolitical processes aimed at gaining new resources and political domination, and post-socialist megacities are involved in it; and the struggle between two adversarial trends - globalization/unification and localization/particularization-will continue. Therefore, there is no single 'owner' of such megacities.
\end{abstract}

Keywords: geopolitics, globalization, IC-technologies, megalopolis, metabolism, ownership, SBT-systems, virtual reality

This question has been posed by the UK urban sociologist Raymond Pahl in early 1970s. He argued that 'urban sociologists must stand firm against the strong pressure by planners to turn them into futuristically-oriented market research consultants, by system and modelling building colleagues, who demand sociological unreality to make their models more tidy, by those who disregard underlying social conflicts in favor of ad hoc amelioration and by social anthropologists, who may be more interested in the mechanisms of social interaction than the source of inequalities in the wider system. I am arguing that truly urban sociology should be concerned with the social and spatial constraints on access to scarce urban resources and facilities as dependent variables and managers or controllers of the urban system, which I take as the independent variable... A new approach to the subject along these lines might be cumulative, might systematically aid our understanding of complex urban society and could have great practical value' (Pahl, 1970: 224).

Why I see valuable the above and other statements of this author? Because some Russian and other cities in some respects are in the same position that of British ones of the early 1970s. Of course, we are entering into the times of a 'digital' revolution, but at the same time many problems of Russian industrial cities have not been yet resolved.

Let us consider the Pahl's statements point by point. Firstly, he argued for a cumulative, systematic approach to the study of any urban system. Secondly, he stands against the pressure 
of city planners to turn sociologists into futuristically-oriented market research advisers as well against those who disregard social conflicts as epistemological and theoretical underpinnings of urban sociology. Thirdly, he stands against city planners because in those times they have been a 'conductors' of industrial technologies and, first of all, of building ones. Fourthly, being initially myself an architect and city planner, I fully understand a negative position of Pahl against the understanding the sociologists as 'futuristically-oriented market research consultants.' In Russian practice we call such 'futuristic projects' as a paper architecture which has nothing in common with social reality. Unfortunately, the development of information-communication technologies gave the way to replacement of sociological facts by dramatized ones. Fifthly, a social inequality issue is today as important as half-a-century ago. Sixthly, Pahl is absolutely right putting forward an issue of access to the scarce urban resources and facilities. Recently, this issue has acquired one of the headlines on global agenda: a world population is growing whereas the accessible resources for them have become more and more scarce. Seventhly, Pahl was against of implicit determinism in much of so called works of human geography.

What have been missed in the Pahl's agenda? To my mind, three points. One is socio-ecological approach to urban studies. He has mentioned the R. Park and his colleagues work but in the respect of rural-urban migration only. Pahl considered the forces that shape an urban organism as 'implicitly ecological, and organize at a biotic or sub-social level of society' (Pahl, 1970: 210,129). The other is already mentioned the absence of analysis of the impact of the ICprocesses on urban structure and function. I am mentioning this fact because the study of such impact has appeared in the 1965. I mean the information theory of urban growth developed by R. Meier (Meier, 1965).

The last point is a socio-ecological approach to urban studies. In cities, as R. Park argues, in terms of such approach a high degree of interdependence and division of labor results in competitive cooperation for space use. As a result, natural areas of the city emerge (Park, 1952). Pahl is partly wright saying that the 'forces which Park mentions are implicitly ecological, and organized at a biotic or sub-social level of society, and it is for this tacit determinism that Park and his followers, the early classical school, have been criticized' (Pahl, 1970: 129).

\section{GLOBALIZATION MAKES THE WORLD MEGALOPOLISES INTERDEPENDENT}

The key processes make them interdependent are metabolic ones. For a long time the sociology being separated from natural and technical sciences considered the interactions as one of its major research instruments. The interactions may be friendly, neutral or negative, but they have been well enough for social-structural analysis. But a social practice more and more leave behind theoretical comprehension of its rather complicated forms. The essence of the issue is that the processes and substances of social, natural and technical origin are 'interacted' each other directly. And the result of such 'interactions' may be of various nature. Actually, there are no interactions in the common sense of the word, there are their mutual transformations. Such transformations have different time duration ranging from immediate results (for example, the mutual annihilation) till the months and years. In the last case there are the processes of risk accumulation. In the basis of various metabolic processes are biochemical reactions (transformations). I call these processes as a 'chemistry' of our life.

As I've mentioned earlier, the globalization is a mighty levelling process. The more globalization process is going ahead, the more the megalopolises across the world are becoming dependent each other. Therefore, these megalopolises more and more acquire a 
'transitional' character that is their structures are subjected to the needs of global stakeholders. It means that all their infrastructures ranging from airports, railway stations, hotels and other urban facilities and all communication infrastructures are guided by the need of these stakeholders. In a manner, they may be seen as the 'tourists.' But the reverse side of the same coin is inter-state commuters who are subjected to the same rules. All of them are needed in standardized means of transportation, shelter, meal, medicine, urban facilities, congress-halls, theatres, etc.

Then, the 'master' of such megalopolis (say, a city council, its government, urban police and other power structures) is, in final analysis, presents a part of such service personnel. It is so because an overall megalopolis 'machine' has to work in favor of the transnationals and their local divisions and branches. A daily population of such cities is a 'fuel' of this machine as well irrespectively whether they live in the city or in its suburbs.

More than that, an emergence of a second reality, a virtual one, means the further transnationalization of the use of urban areas. The each re-translator should overlap the areas of neighboring re-translators irrespectively what is going on a city surface. On the other hand, the emergence of global information-communication network makes distant communication very easy. This phenomenon is called as a 'converting a space into time.'

All said above means that the further the more urban 'greening' (that is, the making of open spaces) acquires now a demonstrative (symbolizing) effect, i.e. to make a particular city more attractive and pleasant for site-seeing.

\section{MULTI-SIDED RISK: CONTRADICTION OF PRIORITIES}

As it has been shown above, our world is full of all-embracing and all-penetrating risks. What is a ladder of priorities in such world? It is not an easy task. There are at least three contradictory dangers of that kind: global war in its modern (hybrid) form, lack of resources needed for billions of people and climatic changes.

To my mind, modern hybrid wars are the most urgent threat to the humanity. In some parts of the world they are already going on, in others one could observe a multiplicity of critical situations (zones), in still others we see a stagnation and disintegration with an emanation of giant masses of energy of decay (refugees, forces migrants, unemployed, etc.). The lack of resources of a vital importance is another all-embracing risk produces by severe exploitation of natural resources and by a pollution of all spheres of living environment. I mean here not only natural resources like drinking water but social resources as well that are needed for the maintenance of human life and wellbeing. This dander is rooted in a consumer-oriented mode of capitalist production. And, finally, there are forthcoming but still uncertain climatic changes. The threat of the hybrid war is the most acute because a majority of world population is well acquainted with such all-embracing risk and its deadly consequences. For Russians, a peace is a first priority because their historical memory keeps the knowledge about the Great patriotic war (1941-45). All people on the earth have become aware of sudden and unintended consequences of hybrid wars. That is why a safety and not ecological wellbeing came now to the forefront.

But recently, the safety has acquired another meaning. Safety means the maintenance of a relatively safe life of urban residents, their children and relatives. In other words, these residents consider a stable mode of living in a relatively long period. But it simultaneously means that these residents well understand that such sustainability may be reached by 
permanent and multisided transformations (permanent learning, migration, by meeting with a diversity of people, cultures, landscapes, etc.).

The lack of resources problem cannot be resolved by individual efforts. In part, it is an 'artificial' problem created by consumer-oriented modern society. The market economy and a modest wellbeing cannot be reconciled. Then, an access to new sources of resources is a part of geopolitics. Besides, a warfare and extra-resource consuming are the two sides of the same coin. More than that, the warfare always means an intensive resource wasting (any kind of arms, explosives, ammunition production, arms race, etc.), and these resources have to be permanently renewed.

The world population is much less sensitive to climatic changes. The memory of individuals and the humanity at large is necessarily keeping the pictures of sharp climatic fluctuations. But they rather inclined to estimate natural disasters as the 'cases' and not as indicators of the forthcoming trends. Therefore, a majority of world population sees the climatic changes as something which may be happen in a distant future. In other words, the people are distinguishing sharp natural events (tornados, floods, and earthquakes) and relatively weak weather oscillations. When Pahl spoke about the necessity of cumulative, systematic approach to the study of any urban system, he didn't mean a nature-city relationships. In those times to the majority of urban sociologists represented the nature as one of many components of a quality of urban life, no more. When I have visited London for the first time in the year of 1974, I'd been shocked by a sharp difference between very small private gardens of a majority of city dwellers and the vast open spaces inside London. Some days later, visiting one of the estates near London, I've been shocked once again when its owner said that all forests around the estate 'till the visible skyline' belonged to him as well.

\section{TO WHOM MODERN MEGALOPOLISES ARE ACTUALLY BELONGS?}

The question 'Whose city?' posed by Pahl about half-a-century ago is still very acute. To my mind, London has already been a global megalopolis because it was a center of a global empire for centuries. And after a decay of the British Empire, London is still functioning as one of the global economic and financial centers of the world. And, as some experts argue, London may even strengthen its global functions despite the Brexit. But let us analyze some key transformations generated by globalization process directly related to the question of this section.

Firstly, one clarification question. What is the very term 'whose city' now actually means? Is it a common or private ownership? To a certain degree, 'yes' but in some respects only. A lot of organizations, groups of interests and people are using any megalopolis around the world without being the owners of its houses, structures, etc. Then, are global stakeholders the 'rulers' of modern megalopolises? The answer is the same: To some degree, 'yes.' Are these stakeholders take part in urban planning in a common sense of the word? The same answer again, etc. Such answers mean that the very term 'whose' should be reconsidered.

Secondly, to my mind, a correct answer may be given in the other epistemological master frames. That is, in the frames of global systemic approach, namely, within the concept of the megalopolis as a subsystem of global sociobiotechnical system (the SBT-system, Yanitsky, 2016). Recently, no one structure or process in the world can be conceptualized beyond this master frame. All local or regional structures and processes should be analyzed as a part and parcel of the global SBT-system. Therefore, our problem should be formulated in quite another form: What are the relationships between global, regional and local 'users' of modern 
megalopolises? Or in other words, which particular agents (forces) only 'use' their potential in their own purposes, which are in-between, and which are only a resource for the two which have just been mentioned?

Thirdly, and it is principled epistemological point: modern megalopolises belong to nobody. They are all of dual nature: global-local. That is, they are simultaneously the agents in some cases and resources in the others. There is a tough struggle between these two trends. Ultraliberals will argue that the global agents will dominate but world geopolitical situation shows that there is a permanent oscillation between global (unifying) and the localization trends generated by the nation-states and their unions and alliances. The result is that recently any form of 'belonging' is always temporal, dependent on changing of global disposition of forces, i.e. of the relationships of major stakeholders.

Fourthly, nevertheless, as S. Sassen argues, 'Global cities are strategic sites for the production of ...specialized functions to run and coordinate the global economy.' But there is a kind of dialectic in relationships between national, i.e. territorially-localized activity, and global one relied upon the informational, resource and labor force flows. That is why, 'while globalization leaves national territory basically unaltered, it is having pronounced effect on the exclusive territoriality of the national state - that is, its effects are not on territory as such but on the institutional encasements of the geographic fact of national territory' (Sassen, 2000: 373-374).

Fifthly, it is now clear that global and local actors exist and act in the same reality that is the global SBT-system, and thus they are tightly interconnected and cannot be separated. Therefore, various global and governmental bodies should remind that local knowledge is a dynamic and socioculturally significant factor, on the understanding of which depends the success or failure of many projects... It should be clear to international institutions that their universalistic approaches, based on global strategies of problem-solving, can only succeed when they are mediated by local knowledge' (Diawara, 2000: 370). M. Diawara stands against a poststructuralist criticism and nihilism insists on taking into account the consideration of the different actors in society and considers how each one takes on its own reality of development (Diawara, 2000: 361).

Sixthly, a quality of daily living is not a permanent (statistical) index, it may vary greatly. Such indexes are highly dependent on given living standards. If a person or family has low income and no prospects to raise it his/her estimation of environmental quality will be one. But with the raising of living standards and the emergence of new opportunities in education, traveling, etc. the perception of environmental quality will change. More than that, the very understanding of 'living environment' will change since an individual gains an access to better food-staffs, medical care and another facilities, to variety of possibilities to spend his/her vocations outside the city, etc. (Whyte, 1977, 1984). It is quite natural that an individual's perception of quality of urban life highly depends on many other factors: gender, age, state of health, family status, etc. Besides, one should take into account that the very perception of a given living milieu depends on the development of new technologies, means of communication, our own ability to shift from one living area to another, and so on and so forth. As Pahl later noted that the work is becoming more polarized, more divided and more disaggregated (Pahl, 1988: 751). It means that the quality of living milieu and its perception by individuals, city managers and urban planners are also permanently changing. Their utmost model of high quality living milieu is compiled from two adversarial wishes: the most standardized and simultaneously the most attractive, i.e. socially and culturally diversified. 
Seventhly, one should keep in mind that social and consequently socio-ecological inequalities are still growing in all cities and towns but especially in modern megalopolises. It is well understandable because the megalopolises are now the most attractive social milieu from the viewpoint of getting work, shelter and prospects of further social mobility.

But again, one could observe a double-sided process. On the one hand, such opportunities are actually grow. In Russia such megalopolises as Moscow, St. Petersburg, Ekaterinburg and Kazan' are the centers in which such opportunities are maximal. On the other hand, these cities are more and more becoming as 'transition sites' like airports and railway stations. For both categories of newcomers the quality of life in these 'transition sites' means nearly nothing. It is correct to another category of migrants, i.e. for the commuters from the cities around such key megalopolises. These migrants didn't show any interest in quality or safety of their temporal milieu. Their aim is to earn money and the more the better, or to find another place of work. Such commuters are never bothered about the state of their immediate or distant milieu. In other words, these people are potentially carriers of infections because as commuters they spend much time in buses and trains.

The above analysis may be summarized as follows. Modern megalopolises are on the move (in transition). They are representing a concentration of various types of social, material and informational capital which is valuable as such. But this capital is not eternal, it have to be permanently renewed. Such megalopolises are simultaneously very mobile and inertial entities. Nevertheless, by and large the global institutional and organizational structures and functions take over locally-organized ones. But this trend is not simply the process of supplanting the former by the latter. Such global-local dialectic has various forms: some functions are extinguishing, others are transforming for serving the needs of transnationals, third are emerging and so on. Then, there are two adversarial trends in these megacities: the raising of their cumulative capital and its diminishing by a permanent influx of migrants from national and global periphery. Both trends are needed in various resources including space. This influx has a dual effect: a minority of newcomers is building in the new spheres of production (information, communication, services and so on) while a majority is concentrated in the ghettos and ethnic neighborhoods within a megacity and its outskirts. As the migrant's influx in the EU showed, it seriously disturbed an overall political sphere of such cities.

Then, the megalopolises are subjected to economic and financial crises. Global financial crisis of the 2008 has a multiplying effect. It seriously destroyed not only a labor and housing market but generated various forms of social protests. After then, a transformation of megacities engendered by information-communication processes is usually slightly seen on the surface of city life because the struggle of their national and transnational agents is going on 'under the carpet', that is at the labor, commodity and financial exchanges, or in the 'cloud space.' That is why the changes in a socio-ecological structure of modern megalopolis will be ever seen as well. For example, the municipalities will continue to widen old streets and built new ones, to set up new open spaces and to renovate old ones. The very globalization process means for megacities a steady process of shrinking natural reserves inside and outside them. But the inner instability generated by the struggle for property, power and political domination will steady grew. As for Russia, the current transition towards digital economy will enhance such instability irrespectively any proposals of its modernization. 


\section{THE CASE OF POST-SOCIALIST MEGACITIES}

In this section I analyze the main features of the transition of Russian cities only (Moscow, St. Petersburg, Ekaterinburg and some others) because the cities on the post-socialist space are still needed in detailed investigation.

First, as any qualitative change of a mode of production, it leads to sharp weakening of social order and the rise of civic initiatives and social movements. I cannot name them a true 'urban social movements' (C. Pickvance). Rather it has been a period of the rise of numerous protest actions and a grassroots activity. During the 1987-91s, in contrast to Estonia and other Baltic republics in which the struggle between the Popular, i.e. nationally-oriented Front and the International Front has been very tough, in Russia the pro and contra mass peaceful meetings have been very peculiar.

Second, such mass meetings have been conditioned not only by interest in domestic politics and its prospects, but first of all by mass unemployment, sharp lowering of living standards, by inflation and by all other features of all-embracing crisis of a communist system. The economic politics of the new government has been aimed at not on the means of renovation of the existing industrial system but at total destruction of it and its replacement by numerous small cooperatives at the expense of labor power and the equipment of stagnating enterprises.

Third, it is indicative that in those times the already done comparative research of public participation and other forms of social movements turned out not needed because a public activity (on all levels, from local to national) has prevailed. My interpretation of this phenomenon is not political but rather socio-psychological: the rank-and-file city residents after a long period of being separated, i.e. alienated, gain now an opportunity to be together, shoulder to shoulder. But these people didn't understand that real power is still in the hands of yesterday communist leaders and captains of big industry. The state capital has been quickly transformed into the capital of new Russian nouveau riches.

Fourth, as I've already mentioned earlier, the above megacities have a great inertia because their buildings, infrastructures, communications, organizations and institutions have actually been the already accumulated capital. And it couldn't been totally destroyed at once. Urban residents, and social capital accumulated by them have been one of the most important form of megalopolises' capital. This capital has allowed survive to the residents of Moscow and other megacities. A part of their residents has transformed into the small retail traders (chelnoki). They supplied the urban population with goods and services of the first priority. It reminds the post-October revolution period (1918-22s) in Soviet Russia but without civil war. Late on and till now, these small traders have created numerous small markets within and outside these megacities.

Fifth, there are two adversarial trends in modern Russian megalopolises. The former is to make their appearance more comfortable, respectable and attractive, first of all to federal authorities and foreign tourists. That is, to construct new highways and railroads, new metro lines and stations, set up new public parks and open areas, and to make an overall city atmosphere saturated by numerous exhibitions, attractions, competitions, etc. The latter is to maximally reduce any forms of self-organized activity of urban residents and to get strict control over any mass protest actions other forms of public self-expression. Even within city neighborhoods any form of self-organization should get a special permission of the municipal or megacity authorities. And usually it takes weeks or even months. The municipal authorities are trying to avoid any forms of protest activity by all means, even sometimes by violation of 
the Russian Constitution. As a result, there is a growing gap between declared and actual human rights and freedoms in a given urban space.

Six, as the beginning of the program of mass renovation of outdated five-storied apartment houses in Moscow built in 1950-60s showed, its residents and other people saw in this program a threat to them as to the private owners of their apartments. Besides, the losses tied with such mass resettling (extra-expenses, noise, etc.) as well as with a necessity to adapt a new living space to their needs only increase their concerns. As a result, the short-term but very energetic housing movement has emerged aimed at the stop of this program. The experts estimated this case differently. Some argued that this energetic protest showed the limits of interests of urban residents to their living milieu: their interest have been focused on their immediate surroundings and no more. Others saw in it a counter-attracting clever stroke of city authorities in connection with the coming municipal and presidential elections. Plus the opportunity for city administration and developers to earn enormous money in the process of implementation of the renovation program that has no time limits.

Seven, the transformations of Russian megacities produced by new informationcommunication technologies are usually slightly seen on the surface of daily urban life but they are of a crucial importance. In the times analyzed by Pahl, urban dwellers lived mainly in one socio-spatial space but now they are living in two tightly interconnected but qualitatively different ones. This gap leads to the loss of interest of city residents to the structures and functions of city life and its shift towards virtual ones. For example, the Moscow residents never seriously bothered concerning the quality of their living milieu because the reaches has a lot of instruments to control it state and to protect themselves if it not fit to their requirements, for example, by resettling to another residential area. The poorest have neither such instruments nor an opportunity to resettle to another place. For the reaches to be permanently in a global information network is not simply a necessity, it is a norm of their life. The poorest are usually totally unmovable in any sense (Bauman, 2001, 2004).

There is one but very important exception. There are cases in Soviet/Russian history when the harm produced by only one small town (namely Baikal'sk) or more precisely, by its pulp and paper mill, had generated the all-Soviet environmental movement. The matter is rather simple: this mill had polluted the lake of Baikal, a unique reservoir of fresh water. Nowadays, due to hackers' attacks across the world a 'spot-globe' difference doesn't work. A small may be potentially as harmful as global one.

\section{CONCLUSION}

Modern megalopolises are simultaneously the results and fertilizers of capitalist mode of production. Three forms of the mode of production are competing in these megalopolises: an information-communication (in the widest sense of the world), the services including tourism, and an industrial one. The former is a driving force to the two latter. It means that there is no single 'owner' of such megacities. Therefore, any suggestions and plans of its renovation, renewal or 'ecologization' will be subjected to the permanent struggle of the above three forces. Besides, it means that any form of its sustainability is only a moment of such struggle.

Is a global market economy is so omnipotent? It is an open question. Up to now all attempts to subordinate its mechanisms to any plans failed. In any times private property, competition and the ideology of personal or/and group success have always been the separating factors. 
Summing up, there is no sole answer to the Pahl's question 'Whose city.' As a local-global, multisided, multileveled very mobile entity which is nonlinear developed, it cannot have a single owner. Some of its structures are relatively open for all others are accessible for some or accessible to a closed circle of top managers or military operators. But it is not all. All functional units of the megalopolis are not necessarily situated in particular sites of it. For the reason of a dual (material-virtual) nature of the megalopolis, many of its structural units is impossible to fix neither spatially nor temporally. In every particular case these units have spatially-fixed and virtual components. Rather these units exists ad hoc that is they are selforganized necessarily from time to time. This phenomenon is conditioned by the very nature of market economy as well as by permanently changing geopolitical situation. In turn, it means that previous representations of a megacity as a certain 'plan' (design) are now not sufficient. In theoretical and empirical studies we should accentuate the processes of permanent transformation of the megalopolises in many directions. For more adequate representation we should to conduct our research in the 3-D format.

Funding the research was supported by Russian Fundamental Research Fund under grant "Russian megacities in the context of new social and environmental challenges: Building complex interdisciplinary model of an assessment of 'green' cities and strategies for their development in Russia", project No 17-78-20106.

\section{References}

Bauman Z. (2001) On Glocalization: Or Globalization for some, localization for some others, in: Bauman Z. The Bauman reader. Malden, MA: Blackwell Publishers Inc., pp. 298-311.

Bauman Z. (2004) Wasted Lives. Modernity and its Outcasts. Cambridge, UK: Polity Press.

Diawara M. (2003) Globalization, Development Politics and Local Knowledge. International Sociology, 2000, Vol. 15 (2): 361-371.

Meier R. (1965) The Communication Theory of Urban Growth. Mass.: MIT Press.

Pahl R. E. (1970) Whose city? And other essays on sociology and urban planning. London: Longman Group ltd.

Pahl R.E., ed. (1988) On work: Historical, comparative and theoretical approaches. Oxford: Basil Blackwell Ltd.

Park R. (1952) Human Communities. The City and Human Ecology. Glencoe.

Sassen S. (2000) Territory and Territoriality in the Global Economy, International Sociology, Vol. 15 (2): 372-393.

Whyte A. (1977) Guidelines for Field Studies in Environmental Perception. Paris: UNESCO.

Whyte A. (1984) Integration of Natural and Social Sciences in Environmental Research: A Case Study of the MAB Program, pp. 298-323, in: Di Castri F., Baker F. and Hadley M., eds. Ecology in Practice. Part II. Paris: UNESCO.

Yanitsky O. (2016) Sotsiobiotechnicheskie systemy: novyi vzgliyad na vzaimodeistvie cheloveka i prirody [Sociobiotechnical systems: A new view on man-nature relationships]. Sotsiologicheskaya nauka i sotsial'naya praktika, Vol. 4, no 3: 5-22.

Available at: http://manuscript.sciknow.org/uploads/ojssr/pub/ojssr_140963345.pdf 